to ensure that nuclear energy for peaceful purposes is used in the safest possible way.

2006 - Muhammad Yunus and Grameen Bank of Bangladesh for their efforts to create economic and social development from below.

2007 - the Intergovernmental Panel on Climate Change and $\mathrm{Al}$ Gore for their efforts to build up and disseminate greater knowledge about man-made climate change.

2008 - Martti Ahtisaari (Finland) for his important efforts, on several continents and over more than three decades, to resolve international conflicts.

2009 - Barack Obama (USA) for his extraordinary efforts to strengthen international diplomacy and co-operation between peoples.

2010 - Liu Xiaobo (China) for his long and non-violent struggle for fundamental human rights in China.

2011 - Ellen Johnson-Sirleaf (Liberia), Leymah Gbowee (Liberia) and Tawakkul Karman (Yemen) for their non-violent struggle for the safety of women and for women's rights to full participation in peace-building work.

2012 - the European Union (EU) for its contribution for over six decades to the advancement of peace and reconciliation, democracy and human rights.

2013 - the Organization for the Prohibition of Chemical Weapons (OPCW) for its extensive work to eliminate chemical weapons.

\section{Sveriges Riksbank Prize in Economic Sciences in Memory of Alfred Nobel}

The Sveriges Riksbank Prize in Economic Sciences in Memory of Alfred Nobel was set up by the Swedish central bank in 1968 . The last ten recipients of the prize, worth $8 \mathrm{~m}$. Sw. kr. in 2013 (the same as 2012 , which was down from $10 \mathrm{~m}$. Sw. kr. for the previous 11 years), are:

2004 - Finn E. Kydland (Norway) and Edward C. Prescott (USA) for their contributions to dynamic macroeconomics: the time consistency of economic policy and the driving forces behind business cycles.

2005 - Robert J. Aumann (Israel/USA) and Thomas C. Schelling (USA) for having enhanced our understanding of conflict and cooperation through game-theory analysis.

2006 - Edmund S. Phelps (USA) for his analysis of intertemporal tradeoffs in macroeconomic policy.

2007 - Leonid Hurwicz (USA), Eric S. Maskin (USA) and Roger B. Myerson (USA) for having laid the foundations of mechanism design theory.

2008 - Paul Krugman (USA) for his analysis of trade patterns and location of economic activity.

2009 - Elinor Ostrom (USA) for her analysis of economic governance, especially the commons, and Oliver E. Williamson (USA) for his analysis of economic governance, especially the boundaries of the firm.

2010 - Peter A. Diamond (USA), Dale T. Mortensen (USA) and Christopher A. Pissarides (Cyprus) for their analysis of markets with search frictions.

2011 - Thomas J. Sargent (USA) and Christopher A. Sims (USA) for their empirical research on cause and effect in macroeconomy.

2012 - Alvin E. Roth (USA) and Lloyd S. Shapley (USA) for the theory of stable allocations and the practice of market design.

2013 - Eugene Fama (USA), Lars Peter Hansen (USA) and Robert J. Shiller (USA) for their empirical analysis of asset prices.

\section{North Atlantic Treaty Organization (NATO)}

Origin. On 4 April 1949 the foreign ministers of Belgium, Canada, Denmark, France, Iceland, Italy, Luxembourg, the Netherlands, Norway, Portugal, the UK and the USA signed the North Atlantic Treaty, establishing the North Atlantic Alliance. In 1952 Greece and Turkey acceded to the Treaty; in 1955 the Federal Republic of Germany; in 1982 Spain; in 1999 the Czech Republic, Hungary and Poland; in 2004 Bulgaria, Estonia, Latvia, Lithuania, Romania, Slovakia and Slovenia; and in 2009 Albania and Croatia, bringing the total to 28 member countries.

Functions. The Alliance was established as a defensive political and military alliance of independent countries in accordance with the terms of the UN Charter. Its fundamental role is to safeguard the freedom and security of its members by political and military means. It also encourages consultation and co-operation with non-NATO countries in a wide range of security-related areas to help prevent conflicts within and beyond the frontiers of its member countries. NATO promotes democratic values and is committed to the peaceful resolution of disputes. If diplomatic efforts fail, it has the military capacity needed to undertake crisismanagement operations alone or in co-operation with other countries and international organizations.

Reform and Transformation of the Alliance. Following the demise of the Warsaw Pact in 1991, and the improved relations with Russia, NATO established security dialogue and co-operation with the states of Central and Eastern Europe and those of the former USSR. These changes were reflected in the publication in 1991 of a new Strategic Concept for the Alliance outlining NATO's enduring purpose and nature, and its fundamental security tasks. Further changes in the security environment during the 1990s led to the development of the current Strategic Concept, published in 1999 to address new risks such as terrorism, ethnic conflict, human rights abuses, political instability, economic fragility, and the spread of nuclear, biological and chemical weapons and their means of delivery. A new Strategic Concept, which reflects new and emerging security threats, was published at a NATO summit meeting in Nov. 2010.

The Euro-Atlantic Partnership. In 1991 the North Atlantic Co-operation Council (NACC) was established as a forum for dialogue with former Warsaw Pact countries. The NACC was replaced in 1997 by the Euro-Atlantic Partnership Council (EAPC), which brings together all 50 NATO and partner countries in the Euro-Atlantic area for dialogue and consultation on political and security-related issues. It provides the overall political framework for NATO's co-operation with partner countries and the bilateral relationships developed between NATO and individual partner countries under the Partnership for Peace (PfP) programme, which was launched in 1994.

Since its launch, the PfP programme has been adapted to expand and intensify political and military co-operation throughout Europe. Core objectives are: the facilitation of transparency in national defence planning and budgeting processes; democratic control of defence forces; members' maintenance of capability and readiness to contribute to operations under the authority of the $\mathrm{UN}$; development of co-operative military relations with NATO (joint planning, training and exercises) in order to strengthen participants' ability to undertake missions in the fields of peacekeeping, search and rescue, and humanitarian operations; development, over the longer term, of forces better able to operate with those of NATO member forces. NATO will consult with any active partner which perceives a direct threat to its territorial integrity, political independence or security. 